Historic, Archive Document

Do not assume content reflects current scientific knowledge, policies, or practices. 

$F 7632 U$

sc 1968
U. S. DEPT. OF AGERCILTURE NATIONAL AGRICULTURAL LIBRARY

SEP 41968
U.S.D.A. Forest Service

Research Paper RM-40

CURRENT SERIAL RECORDS

\section{CONVERSION OF GULLLES TO VEGETATION-LINED}

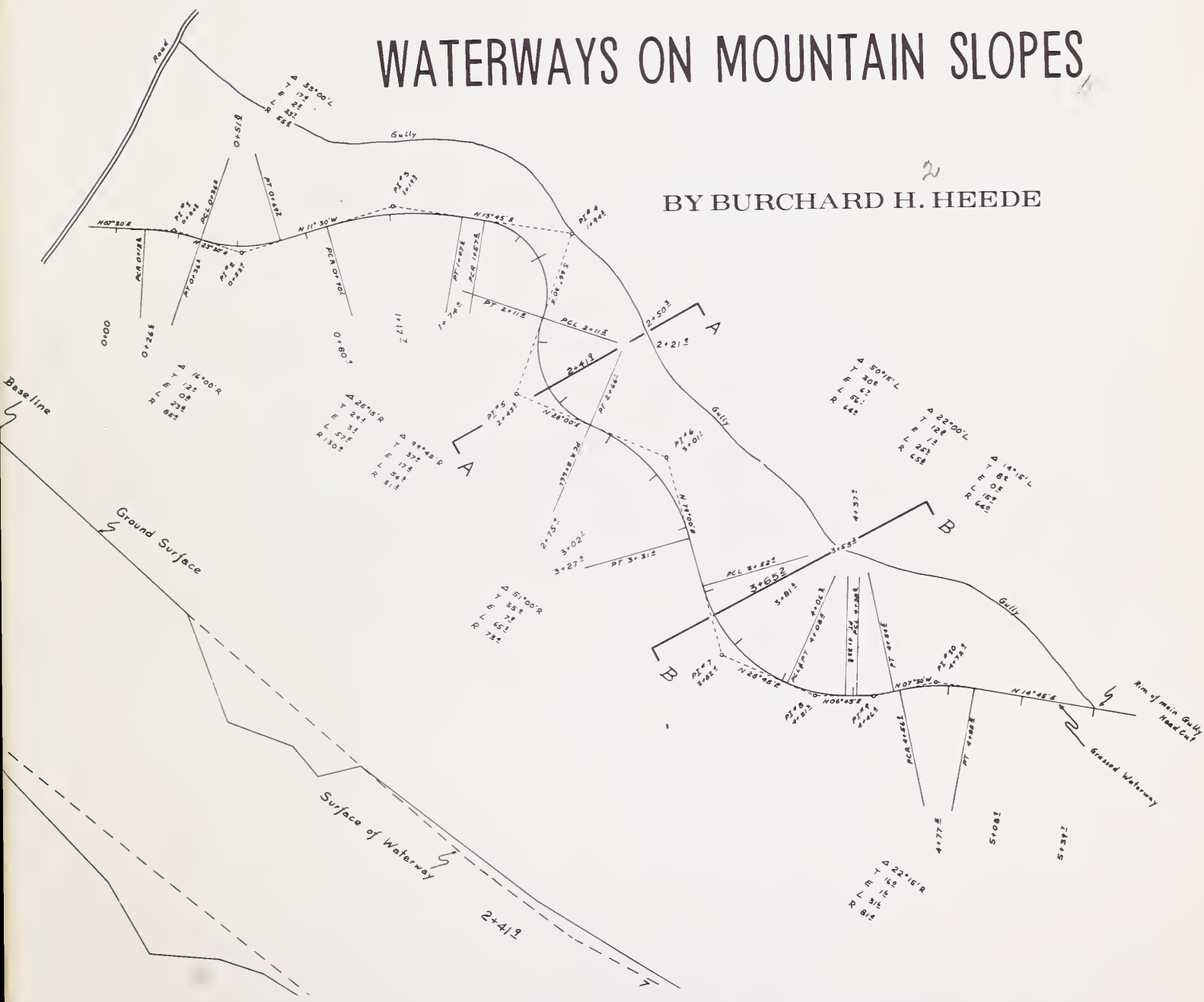

7 (U.S.Rocky Mountain Forest and Range Experiment Station, t 7a Forest Service, - U.S. Department of Agriculture 



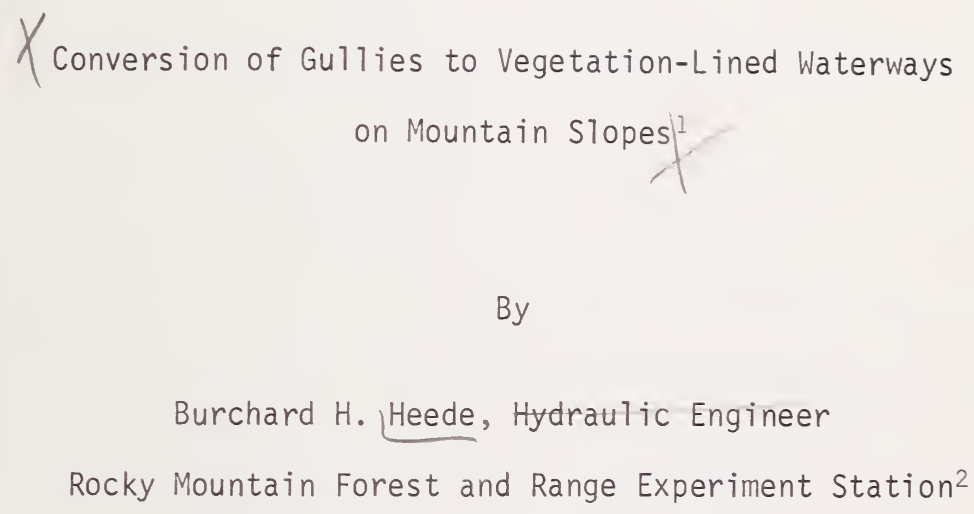

${ }^{1}$ The study was performed in cooperation with the Rifle Ranger District, White River National Forest, and the Regional Office of Forest Service, Region 2, Denver, Colorado.

${ }^{2}$ Central headquarters maintained in cooperation with Colorado State University at Fort Collins. 


\section{CONTENTS}

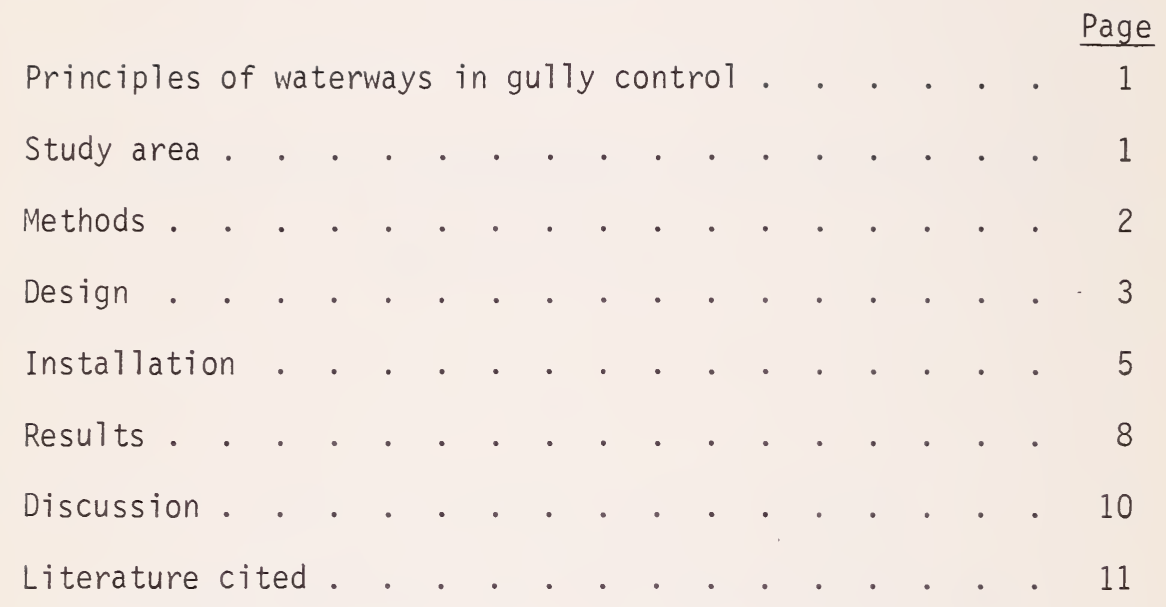




\title{
Conversion of Gullies to Vegetation-Lined Waterways on Mountain Slopes
}

\author{
Burchard H. Heede
}

\section{Principles of Waterways in Gully Control}

The objective of this study was to test the effectiveness of carefully engineered and revegetated waterways for treatment of steep, gullied hillsides of a watershed in the Colorado Plateau Province.

The control of gullies is an old problem. Two contrasting approaches were developed in the past. One involves control of the existing channel by check dams, the other favors construction of a new watercourse with reduced slope gradient and hydraulically inefficient cross sections, that is, the wetted perimeter of the flow is close to maximum. Both approaches change the flow regimen and decrease the erosion energies of the water.

The flat cross sections of waterways favor the establishment of vegetation if the flows are ephemeral during the growing season. An effective plant cover is essential to success; without it, new erosion will take place.

In contrast, if check dams are placed in a gully, channel side slopes remain steep and unfavorable to the growth of vegetation for some time after treatment until the stabilization processes, induced by the dams, lead to more gentle and stable gully side slopes.

Thus, vegetation-lined waterways, if successful, will stabilize a gullied hillside more thoroughly than a check dam system during the first years after construction. During this period, however, the risk of waterways is certainly greater than that of check dams because the establishment of vegetation depends in part on uncontrollable factors such as precipitation and temperature.

\section{Study Area}

The study area is located on the Upper Alkali Creek watershed of the Rifle Ranger District, White River National Forest, 20 miles south of the town of Silt, Colorado. The area is part of the Uinta Basin of the Colorado Plateau Province, and comprises about 1 square mile. Elevation rises from 7,500 to 8,500 feet. The gullies carry water only during spring snowmelt and intense summer storms.

Rocks of the watershed are of the tertiary Wasatch formation, which consists chiefly of variegated clay shale and irregular, crudely bedded sandstone. The sandstone varies from fine to coarse grained and, in places, is strongly calcareous. In general, the soils of the area are predominantly formed from the fine-textured, loose, unconsolidated shales with an admixture of sand from beds of sandstone (Fox and Nishimura 1957).

The parent materials have given rise to soils with clay to clay loam surfaces and heavy, plastic subsoils. The average soil has a clay texture. With the exception of phosphates, the soils contain sufficient amounts of the essential elements for the growth of plants such as wheatgrasses and brome.

The area is representative of the oakbrushsagebrush-grasslands of the western slope of the Rocky Mountains in Colorado. Jakbrush ${ }^{2}$ occupies mainly the upper parts of north-facing slopes, while sagebrush and grass make up valley bottoms, depressions, and south aspects. Dominant grasses are Kentucky bluegrass and western wheatgrass. Individual plants of snowberry and serviceberry are scattered over the watershed. Cattle have been fenced out since 1959.

Precipitation is the only climatic factor measured on the study area. During the period 1962-65, yearly precipitation averaged 18.5 inches. This precipitation consisted mainly of rain between May and September, and snow for the remainder of the year. The growing season starts with beginning of May after most of the snowpack has melted, and ends during the last days of August when the first night frosts prevent further growth. Precipitation for the growing season averages only 5.3 inches, or 29 percent of the yearly total.

\footnotetext{
${ }^{2}$ Common and botanical nomes of plants mentioned are listed on $p .11$.
} 


\section{Methods}

Four gullies of medium size were selected for treatment (fig. 1, table 1). To represent the major aspects of the watershed, the gullies were chosen on north, south, and southwest aspects. Four gullies with aspects similar to those of the treated gullies and located adjacent to them were selected and left untreated, to evaluate future treatment effects.

Waterways were designed from plots of the field survey data. The designs were checked against actual conditions in the field and changed if necessary.

When construction was finished, all disturbed areas were planted to grass and resurveyed according to the pretreatment survey grid. This posttreatment survey disclosed any discrepancies between design and construction, and also served as the basis for the survey at the end of the study period in 1965 . The crosssectional data of the 1965 survey were plotted on the cross-section plottings of the posttreatment survey, and volumes of erosion and deposition were calculated by use of end-areas. Elevation differences between the posttreatment and the last survey of 0.2 foot were not considered significant.

For comparison of erosion between waterways and gullies, it is necessary to know storm intensities and durations, and if individual storms struck treated and untreated gullies alike. A network of precipitation gages was installed, consisting of one recording gage at

Table 1.--Characteristics of the original gullies and the subsequent waterways

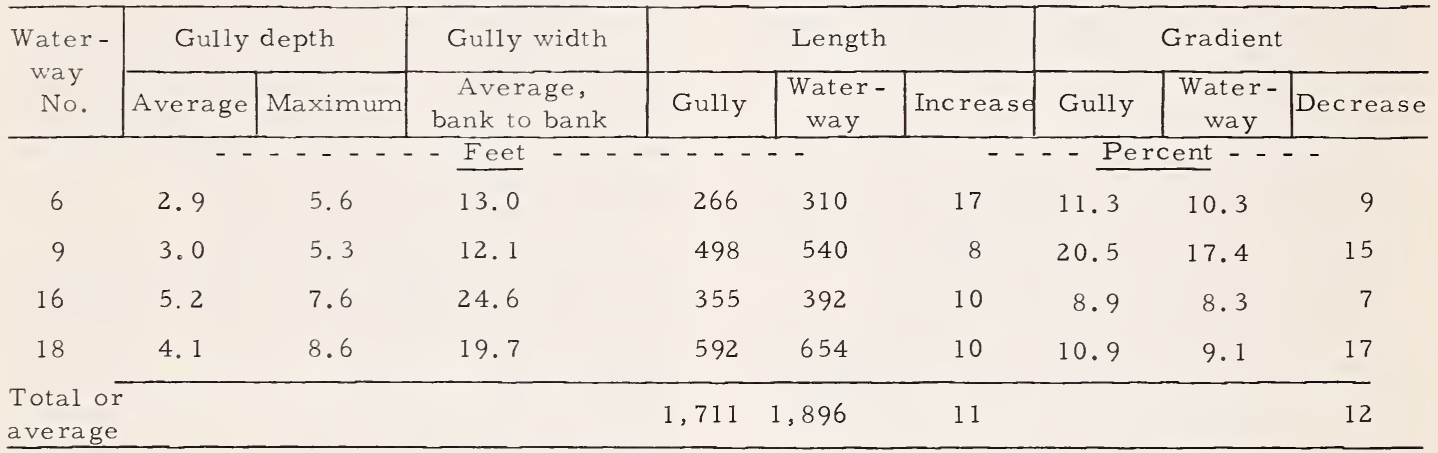

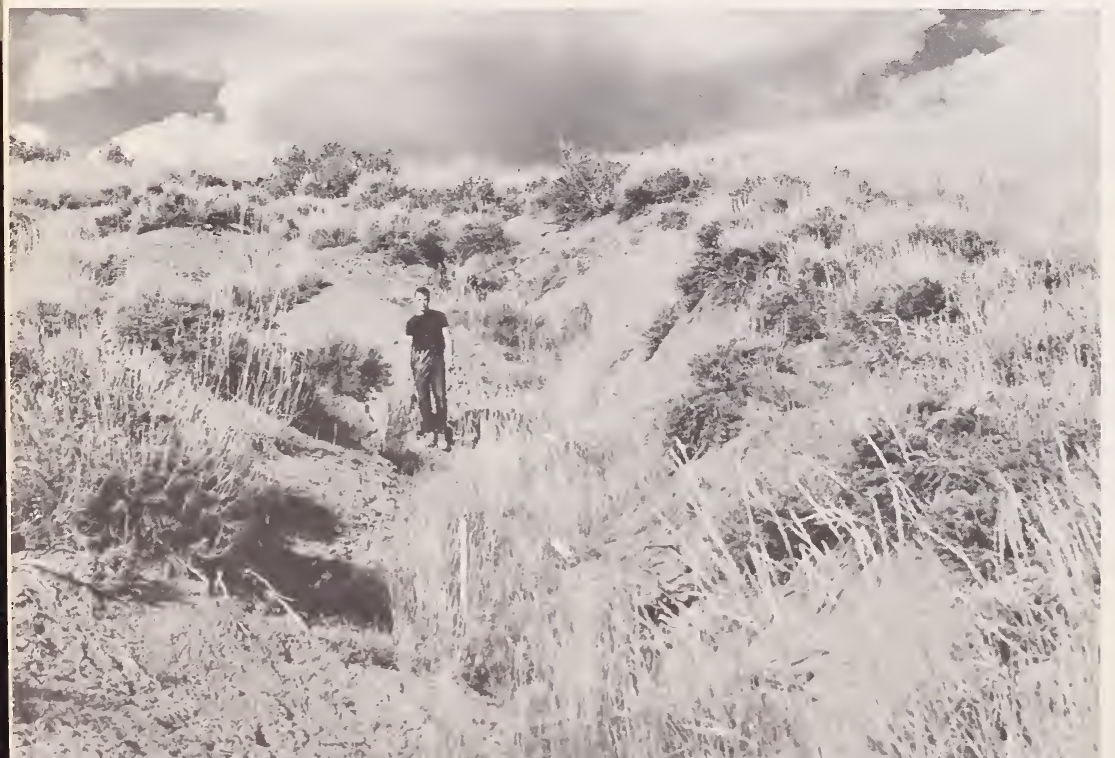

Figure 1.--Gulzy No. 12 typifies conditions that existed before waterway constmuction. 
the approximate center of the watershed, and seven standard U. S. Weather Bureau gages in the proximity of the gullies.

Simple crest stage gages (Heede 1967) were placed at the mouths of both waterways and untreated gullies to (1) indicate whether waterflows occurred while observers were not on the area, and (2) to make possible estimates of peak flows. Due to lack of channel controls at the places of installation, these estimates were rough and should be considered as orders of magnitude only.

\section{Design}

The number of gullies that met the general design criteria was limited on the Alkali Creek watershed. These criteria were as follows:

1. Place waterway on undisturbed soils away from the fill placed in the existing gully;

2. Increase the length of waterway over that of the original gully and thus decrease the gradient of the thalweg;

3. Design broad, flat cross sections that allow waterflows to spread;

4. Establish as quickly as possible grass or other low-growing vegetation on waterway and all other disturbed areas.

Thus to be suitable, gullies should be located on valley bottoms or smaller topographic depressions that provide sufficient space for long and winding waterways. Gully dimensions should be small relative to the land surrounding the channel. Otherwise deep cuts into this land for filling the gully will be required. The watersheds of the gullies should have relatively deep topsoil, adequate for spreading over all disturbed areas after construction. Excessive steepness may limit application of waterways. On the study area, the second steepest gully was selected. The steepest gully, with a gradient of 29.0 percent, was rejected because small gullies did not serve the purpose of the study.

After plan and cross sections of gullies and respective drainage areas were plotted from field survey data, waterways were designed by a combination of graphical and mathematical methods (fig. 2).

Formulas and design procedures for waterways that had been established empirically by older research (Cox and Palmer 1948, Ree and Palmer 1949, Chow 1959) were not applicable to the design of waterways on slopes of the Rocky
Mountains. In this older research, grass species differed from those applicable to the Rocky Mountains, and slope gradients were gentler. Plants and gradients both influence the roughness of flow-a parameter most important in flow and channel stability calculations and very difficult to estimate. Thus specific design criteria had to be established without the benefit of previous research. As a result, many values could be expressed in qualitative terms only. The following criteria were applied:

Fill sections were not permitted on the watercourse itself. Average depth of cut was kept at 1.5 to 2.0 feet to prevent exposure of deeper strata of subsoils. Depths of more than 3 feet were permitted only where shallow cuts were not practical and where the soils were deep. Sharp bends were not allowed.

Curves were designed to be as gentle as possible, since neither the mechanics of bend formation, nor the degree of curvature permitting safe conveyance of water are known. The criteria which made the design work difficult was the requirement for balanced volumes of cut and fill materials, after allowance for shrinkage. Areas covered by surpluses or bared by borrow pits might contribute to new erosion.

The length of the waterways could be increased over that of the gullies by an average of 11 percent, while the gradient decreased by an average of 12 percent (table 1 ).

Changes in the longitudinal gradient of the new watercourse, and differences between upstream and downstream gradients were kept small. The largest difference occurred on waterway No. 9 with a change in gradient of 3 percent. To avoid a pronounced breaking point, because such points lead invariably to future knickpoint formation and a new gully, a vertical curve with a radius of 100 feet was designed at the location of the gradient change. This was also done at all other breaking points.

Waterways have two transition zones: one at the upstream end where the undisturbed drainage joins the waterway, the other at the downstream end where the mouth of the waterway discharges the flow (fig. 3). Both places received special attention in the design to achieve gentle transition.

Minimum bottom width of the watercourse was designed at 12 feet to correspond to the general length of cutting blades on tractors. Side slopes of the watercourse were designed to be as gentle as possible and not steeper than 5:1. This limit was established arbitrarily. 


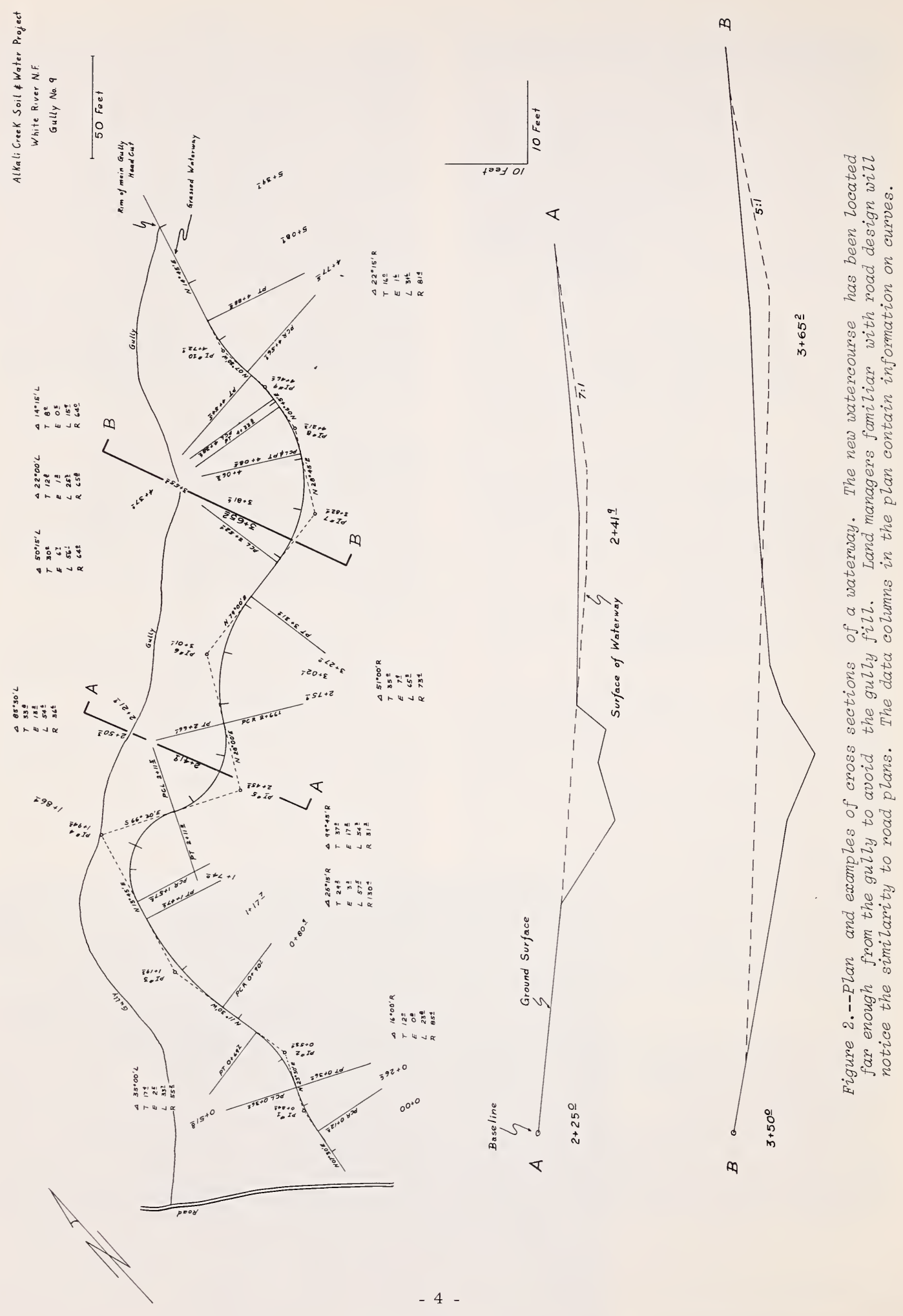


Figure 3.--The former gully of this watemway had an average gradient of 20.5 percent. Gradient of the new watercourse is 17.4 percent. Note the transition zones from the undisturbed hillside into the starting area of the watemay and between mouth of watemay and hillside.

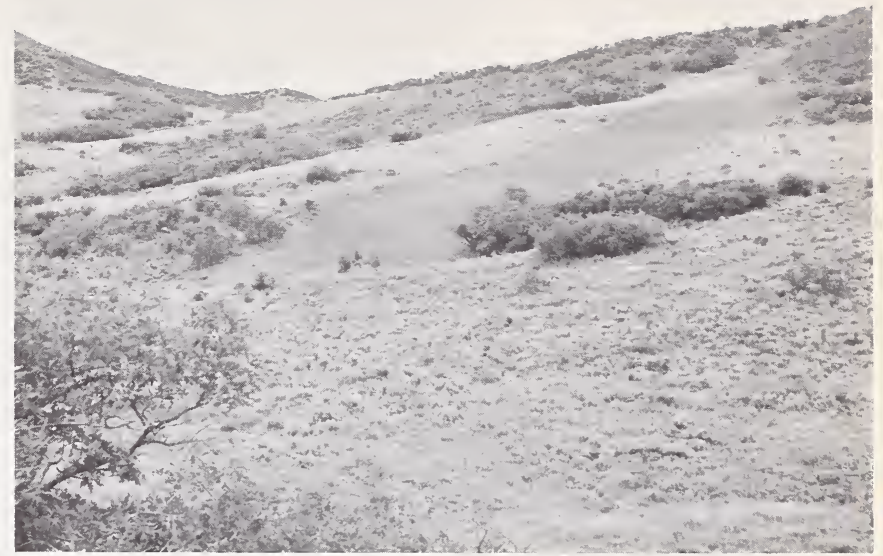

Gully fills were sloped toward the watercourse of the waterway to prevent concentrations of water that might saturate these areas, since during the period following treatment, the risk of mass soil movement induced by water lubrication is great. Ground surfaces of gully fills were raised about 0.5 foot above the design elevation to allow for possible settlements.

Mass curves were constructed to indicate direction and the shortest length of transport for the earth-moving equipment. These calculations proved very helpful and timesaving during construction.

\section{Installation}

For a successful and economic earth-moving operation, select a season in which soil moisture is at a level favoring excavation and effective soil compaction. In waterway construction, it is also important to do the earth moving shortly before or at the beginning of the growing season to permit vegetation to grow after construction is finished. Otherwise, drastic erosion may take place if the soils become saturated during several weeks of spring melt flows.

Based on these considerations, the beginning of May was chosen as the most favorable time for construction. Construction of waterway No. 6 was unavoidably delayed until mid-November. It is believed that this unfavorable time of construction was the reason for higher construction and maintenance costs.

Construction equipment consisted of tractors with cutting blades and sheepfoot rollers. To allow compaction of narrow fill areas, it was advantageous to use only one roller, which could be drawn by a lightweight tractor (D-4). ${ }^{3}$ A heavier tractor (D-7) ${ }^{3}$ was employed for earth cutting and filling. The lightweight tractor assisted the heavier equipment in spreading the soil on the fill areas before compaction. The construction was intensively supervised.

Before gullies were filled, all brush growing on gully side slopes and bottoms were removed by the tractors. During brush removal, the gully surfaces were scarified to allow an effective contact between gully surfaces and the fill materials. To prevent burying of detached vegetation, a man followed the tractor and threw all larger twigs, branches, and roots beyond the boundary of the area to be treated.

The topsoil was then stripped from the treatment area. The surface soils were piled at several places surrounding the stripped land to shorten the hauls during piling and later spreading.

The main cutting, filling, and compaction operations started at the upstream end of the gully. The heavy tractor moved along the contour lines with its blade cutting and transporting the soils into the gully. The smaller tractor, with sheepfoot roller attached, spread and compacted this material in the gully. Volumes of soil deposited in the gully at a time were restricted to layers not thicker than 0.5 to 1.0 foot. It was believed that thicker layers would impede the effectiveness of rolling.

3 Trade nomes and company nomes are used for the benefit of the reader, and do not imply endorsement or preferential treatment by the U. S. Department of Agriculture. 
During the last phase of the earth-cutting operations, the tractor moved along the alinement of the waterway for detail cleanup work, while the sheepfoot roller was drawn over the whole disturbed area. This rolling scarified the surface where the blade had caused surface compaction, and smoothed local surface roughness that would hinder later spreading of the topsoil.

Finally, the topsoil was put back on the disturbed area. The blade of the large tractor was used for spreading; the sheepfoot roller followed. For temporary cover, a mixture of an annual ryegrass and yellow sweetclover was broadcast seeded on all disturbed areas at rates of 50 and 15 pounds per acre, respectively. A rake was drawn over the area to cover the seeds.

To establish a perennial cover, a mixture of grasses and clover at a very heavy rate of 40 pounds per acre was applied in fall. Of this, 60 percent was smooth brome, 20 percent intermediate wheatgrass, and 20 percent yellow sweetclover. Before planting, the surfaces were scarified by a disc drawn by a team of horses. Horses were used to avoid vehicle tracks, preventing undesirable concentration of runoff. The mixture was planted with a shoe-type drill to cover the seeds adequately.

How shape of the cross sections influenced erosional processes could be observed during snowmelt, when the vegetation cover was still very sparse. Where the cross sections were broad and flat, the flows spread on the watercourse and never attained a depth greater than
0.3 foot. Only minor rilling occurred, with a maximum rill depth of 0.05 foot. But where the cross sections were V-shaped, even though the V's were very flat, the flow concentrated at the low point of the $\mathrm{V}$ and started to cut discontinuous rill gullies. These rills obtained a depth of 0.75 foot and a maximum width of 1.0 foot. The relationship between the crosssectional shapes and the magnitude of erosion was so pronounced that rill gullies could be used as indicators for V-shaped sections.

To prevent the formation of continuous gullies during future spring melt flows, burlap checks were installed at a spacing of 5 feet in the fall of 1964 on those parts of the watercourses where discontinuous rill gullies had started. The checks consisted of sheets of burlap folded into strips approximately 0.75 foot wide. Trenches, crossing the watercourses at right angles, were dug with a plow pulled by a team of horses. The strips were placed in these trenches so that 0.2 foot remained above ground level (fig. 4). Then the trenches were filled and grass was sown on the disturbed areas. These burlap checks prevented the fusion of the discontinuous rill gullies during the following snowmelt flows. Because the checks forced the flows to spread out, soil was deposited upstream from the checks, and the rills decreased in size.

Soil volumes moved during construction and costs of installation are shown in table 2 . The volumes moved per linear foot of waterway must be considered in terms of the total width of the disturbed area. Since the average width

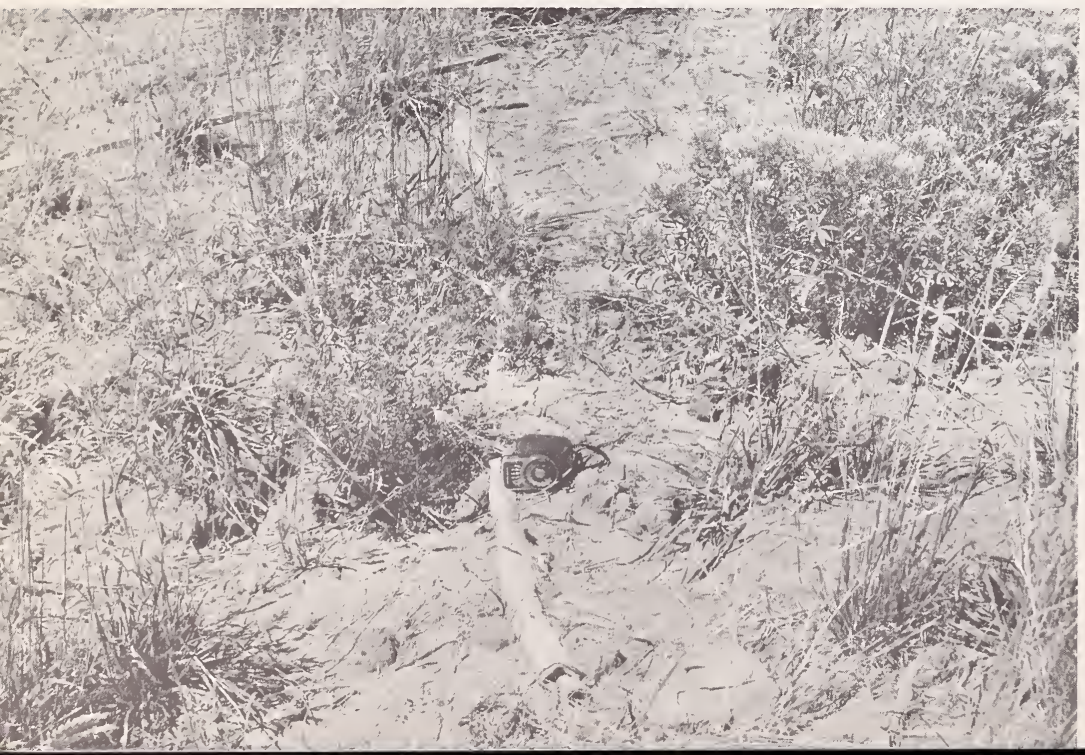

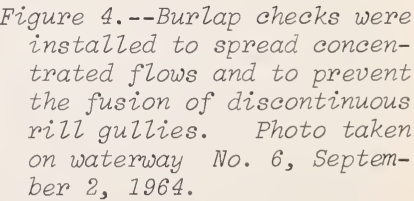




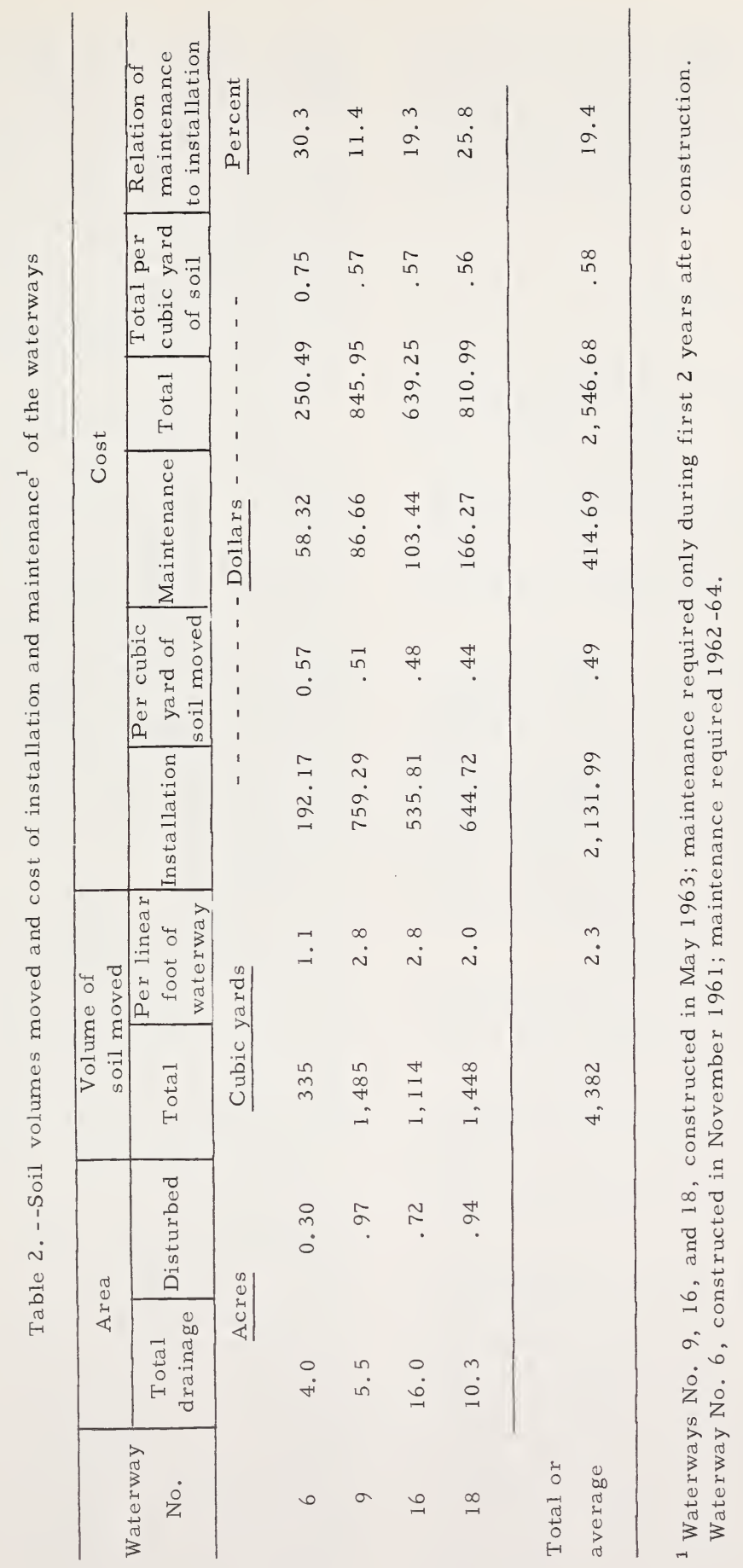


of the disturbed area for all waterways was 75 feet, only an average of 0.83 cubic foot of soil was moved per square foot of waterway surface. The average cost of $\$ 0.49$ for the movement of 1 cubic yard of soil appears to be very low when this cost is considered in the light of the relatively small total volumes.

\section{Results}

During the first year of establishment, the majority of the plants on the waterways were annual and biennials such as ryegrass and sweetclover, respectively, and thus did not meet the requirements for a permanent plant cover. Plants that invaded from the surrounding areas plus those preserved in the topsoil added to the cover and furnished a great variety of species; a total of 31 was counted. Yet, in spite of the great number of species, the plant cover was sparse.

To foster the growth of perennial grasses, the waterways were fertilized with ammonium phosphate (13-39-0) at a rate of 110 pounds per acre and triple superphosphate at a rate of 60 pounds per acre. It was hoped that these rates would offset the phosphate deficiency for grasses such as smooth brome and intermediate wheatgrass, indicated by soil analysis. The fertilizers were broadcast. A harrow, drawn by a team of horses, scarified the ground surface and covered most of the fertilizer.

A survey of waterways at the end of the third growing season after treatment, September 1965, revealed that the dominant plant species were smooth brome and intermediate wheatgrass. These species did not permit the occurrence of rills during the last year of treatment. Litter accumulated on the ground surface, and ryegrass and other herbaceous nongrass species had practically disappeared. The vegetation was judged as dense.

A total of 14 cloudburst storms fell on the waterways during the period of investigation. Greatest storm intensity was 1.9 inches per hour for a period of 5 minutes; largest total volumes was 0.74 inch. This storm occurred during the second growing season after construction. The largest peak flow caused by cloudbursts took place during the first growing season after treatment, on August 20, 1963. It was recorded by the crest gage of waterway No. 16 which indicated a depth of flow of 0.2 foot. It was estimated that the peak carried about 2 c.f.s. Runoff from the high-intensity storms caused some rills on the waterways during the first 2 growing seasons, but their depth did not exceed 0.1 foot.

Abnormally extended spring melt seasons had much greater impact on the waterways than did the summer storms. Snowmelt in 1964 and 1965 lasted 6 and 7 weeks, respectively. During these periods the meltwater was flowing nearly continuously, and the surface soils were saturated. Small, discontinuous gullies occurred during the first snowmelt after treatment, but were controlled and healed by the installation of burlap checks.

During September 1965, all waterways and untreated gullies were resurveyed and the volumes of erosion and deposition calculated (table 3). All water courses experienced net erosion except No. 6, where total deposition was larger than total erosion. This seemed surprising since soil disturbance was extensive during construction, and subsequent vegetation cover of this waterway was too weak for 2 growing seasons after treatment to resist erosion effectively. It was explained, however, by an extensive erosion area above the waterway. Surface runoff from this area was heavily loaded with sediment that could not be carried through the waterway, because the latter represents an inefficient channel for the conveyance of water and sediment.

A comparison of the net erosion volumes of the individual waterways with those of the nearby untreated gullies shows that less material was eroded from the waterways in each case (table 3). This was consistently true if the volumes were compared in terms of soil removal per linear foot of watercourse, or in inches depth on the entire drainage area. Average soil loss from the treated watersheds was only 5 percent of that from the untreated.

Since cost figures for check dams were available for the same years at other gullies on Alkali Creek watershed (Heede 1966), a comparison was made between check dams and waterways. It showed that, for the control of 1 linear foot of gully, $\$ 1.26$ was expended for the construction and maintenance of waterways and $\$ 1.37$ for check dams. The difference of 8 percent is not significant. Far more important, however, is the fact that 19 percent of the original cost of installation was expended for the maintenance of waterways (table 2), while only 4 percent was required at the check dams. This difference in required intensity of maintenance may be important for the practitioner. 


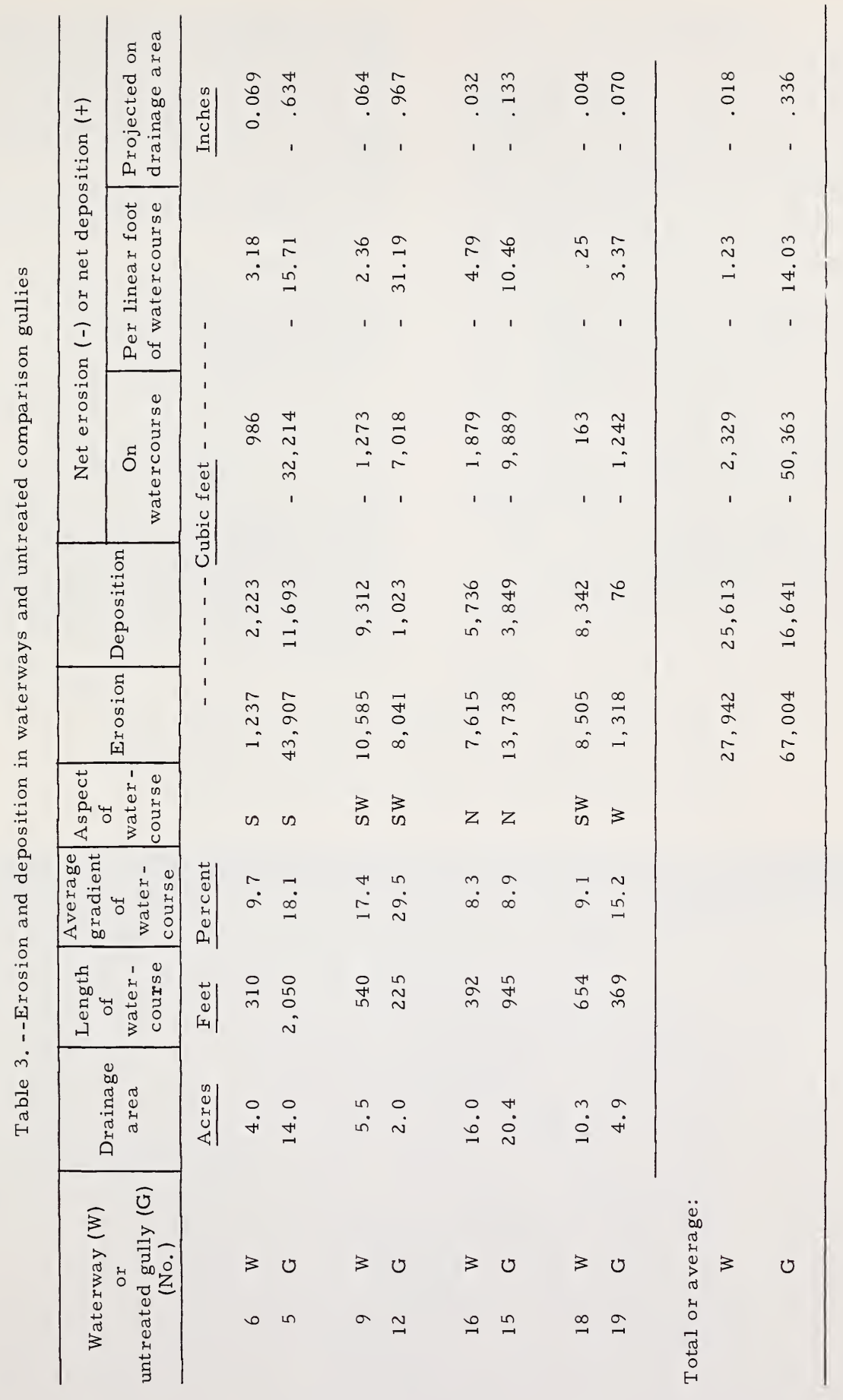




\section{Discussion}

This study constituted an empirical approach to the conversion of gullies to vegetation-lined waterways. Most design and construction specifications could be stated in qualitative terms only, due to lack of knowledge about factors basic to erosion such as: required density of the vegetation cover with a given composition, located on a specific slope and a given soil type; permissible degree of curvature for bends of vegetation-lined waterways with steep gradients; permissible values of resistance to flow in waterways with steep gradients before establishment of vegetation; and effective plant species in slope erosion control which require short periods of establishment under given climate, soils, and topographic conditions. Once knowledge of these waterflow-soil-vegetation relations has been increased, design specifications can be strengthened, and limits of applicability of waterways established.

These field investigations should be regarded, therefore, as a first approach to studies of waterways on mountain slopes. They did not yield specific solutions to important problems in the flow-soil-vegetation relations. Its main merit is to have demonstrated that, under the prevailing conditions, gullies on mountain slopes can be successfully converted to vegetation-lined waterways (fig. 5). This was illustrated by the facts that:

1. A permanent plant cover was established which prevented further rilling of the ground surface.

2. Maintenance was not required during the last year of study, and

3. Per linear foot of watercourse, the waterways lost an average of 91 percent less soil than the untreated gullies.

At the present state of knowledge, it is not advisable to construct extensive waterways on sites not comparable to Alkali Creek watershed. Land managers should test this method further on an experimental basis where intensive design and close supervision are available. The prime requisites for a successful applicationprecipitation, temperature, and fertility of soils favorable to plant growth-will decisively influence the quality of the future vegetation
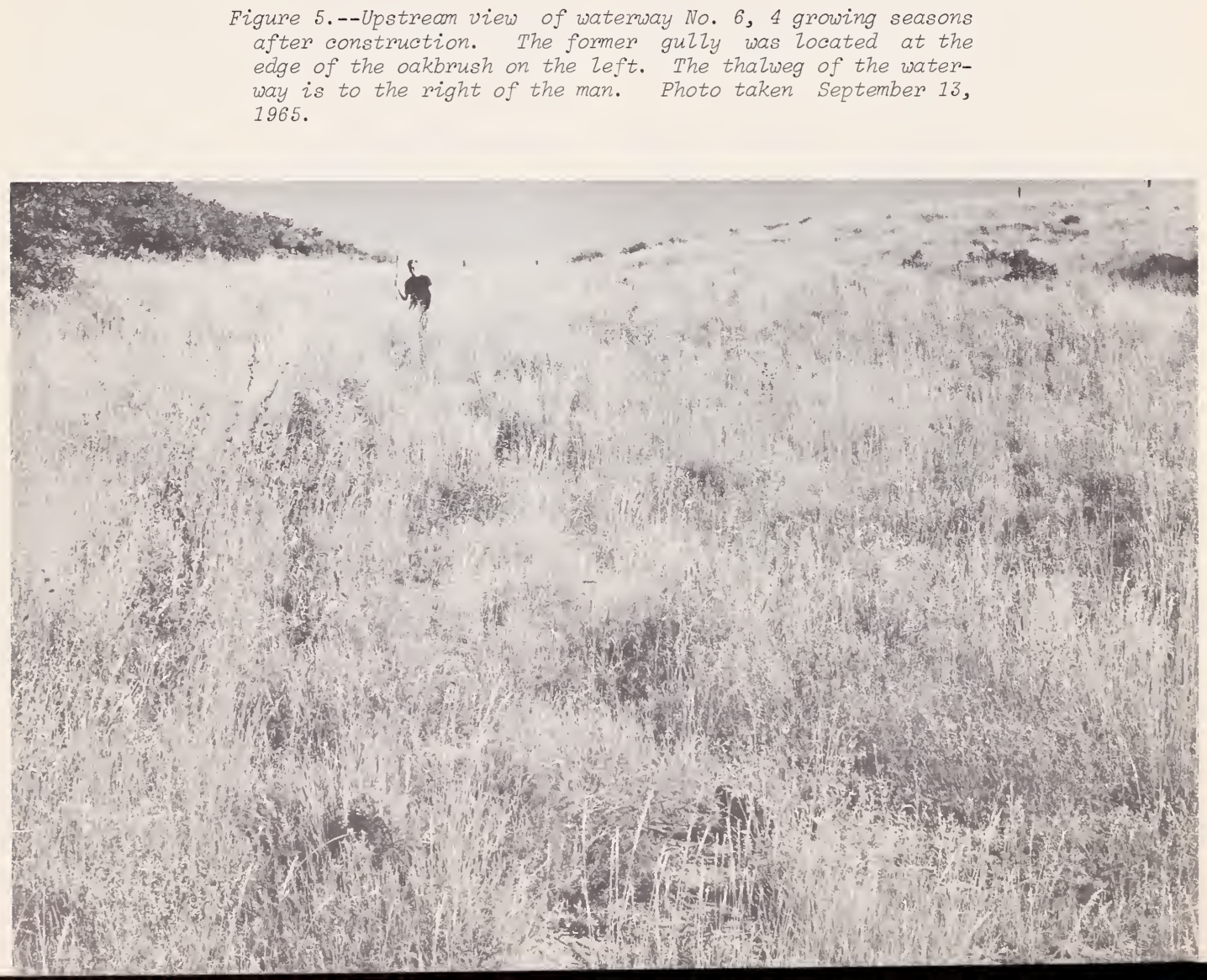
cover which, in turn, will determine the longevity of the waterways. Another important aspect of design is the selection of gullies suitable to this treatment, which should be determined by:

1. Size of gully relative to available fill volumes;

2. Width of valley bottom or depression for placement of waterway;

3. Depth of soil mantle for shaping of the topography; and

4. Depth of topsoil for later spreading on all disturbed areas.

Most importantly, additional studies should not only test the method under various conditions, but above all, should consider the basic relations discussed above.

\section{Literature Cited}

Chow, Ven Te.

1959. Open-channel hydraulics. $680 \mathrm{pp}$., illus. New York: McGraw Hill Book Co. Cox, Maurice B., and Palmer, Vernon Y.

1948. Results of tests on vegetated waterways and methods of field application. Okla. Agr. Exp. Sta. Misc. Publ. MP-12, $43 \mathrm{pp}$, illus.
Fox, C. J., and Nishimura, J. Y.

1957. Soil survey report of the Alkali Creek watershed area.* U. S. Forest Service, Region 2, Denver, Colo., $43 \mathrm{pp}$.

Heede, Burchard $\mathrm{H}$.

1960. A study of early gully-control structures in the Colorado Front Range.* U. S. Forest Serv. Rocky Mountain Forest and Range Exp. Sta., Sta. Paper 55, 42 pp., illus. Fort Collins, Colorado.

1966. Design, construction and cost of rock check dams.* U. S. Forest Serv. Res. Pap. RM-20, 24 pp., illus. Rocky Mountain Forest and Range Exp. Sta., Fort Collins, Colorado.

1967. The fusion of discontinuous gullies. Int. Ass. Sci. Hydrol. Bull. 12: 42-50, illus.

Ree, W. O., and Palmer, V. J.

1949. Flow of water in channels protected by vegetative lining. U. S. Dep. Agr. Tech. Bull. 967, 115 pp., illus.

*Address requests for copies to originating office.

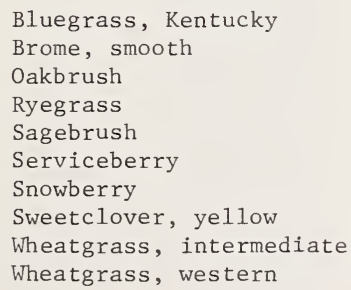

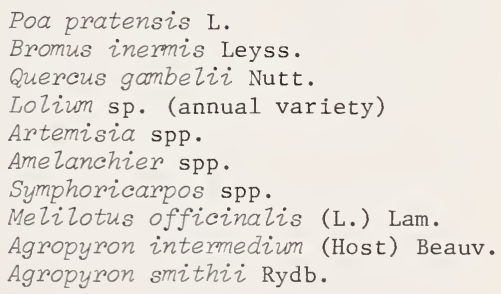





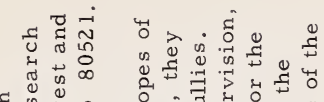

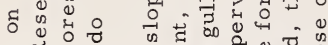

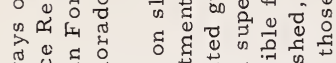

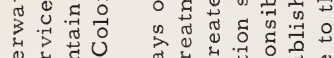

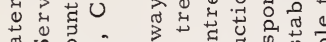

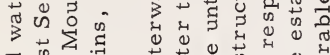

0 0 क

द्व

员乐范

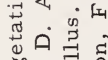

$\infty_{\infty}^{\infty}$ i

में 究

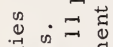

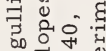

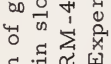

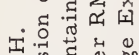

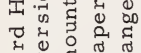

क्ष

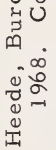

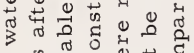

$\circ$ 我究

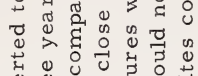

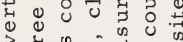

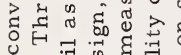

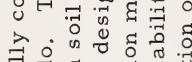

3ี

o

0
0
0

क

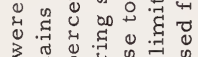

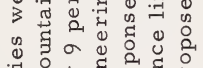

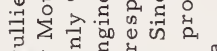

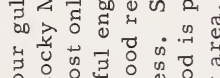

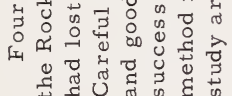

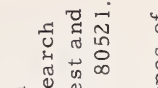

5 0 is

on कै क्ष

ते 0.50

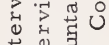

एँ

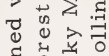

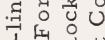

की म्य

总我点

$\sum_{>}^{\infty}$ i $=$

○े

$\stackrel{0}{0}=\overrightarrow{\text { है }}$

क्

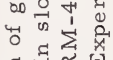

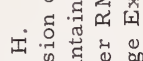

它

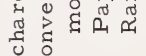

究 0

đृ

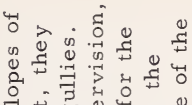

जे

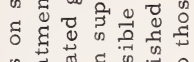

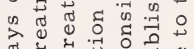

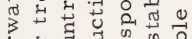

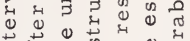

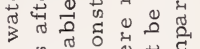

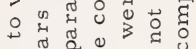

व.

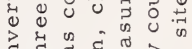

ठี

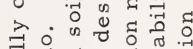

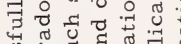

然

0
0 i n 000

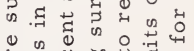

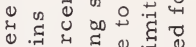

3 势

\%

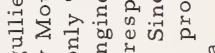

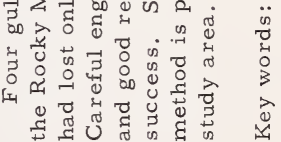

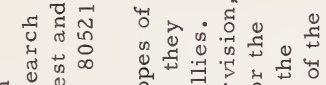

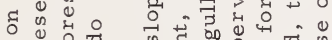

ज在纯

ब.

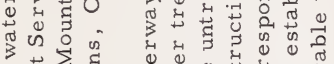

o

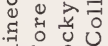

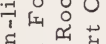

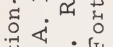

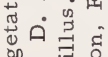

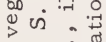

○े

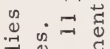

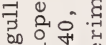

पै के

.

庄.

वृ द्व द्व $\Omega_{1}^{\infty}$

ஸैं

की

웅

零

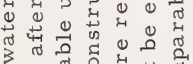

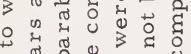

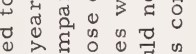

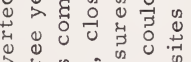

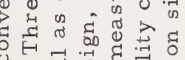

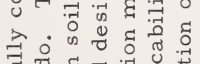

藏

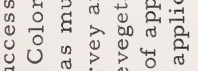

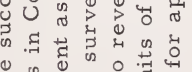

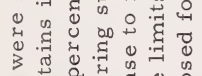

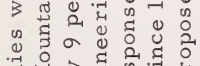

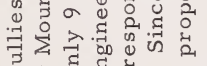

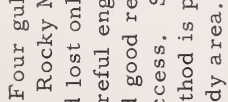

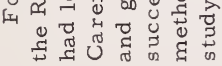

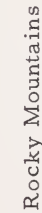

군
둘 $\vec{\pi}$

प्र

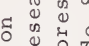

的为

ते 0.150

प

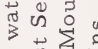

व

चั

दि द्य

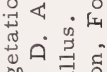

$\sum_{>}^{\infty} \dot{\infty} \cdot-$

무용

क $=\overrightarrow{\text { है }}$

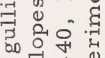

फल

도용

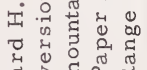

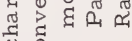

ํํㅇ

ต

बi

茫

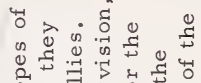

के

ᄃ

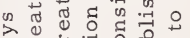

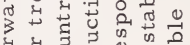

प्र मै ?

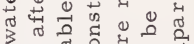

$\circ$ 잉

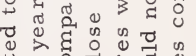

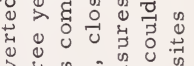

究热

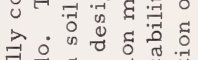

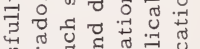

का

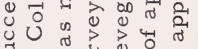

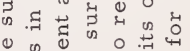

势

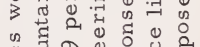

o

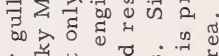

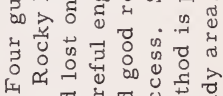

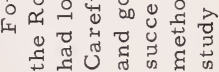




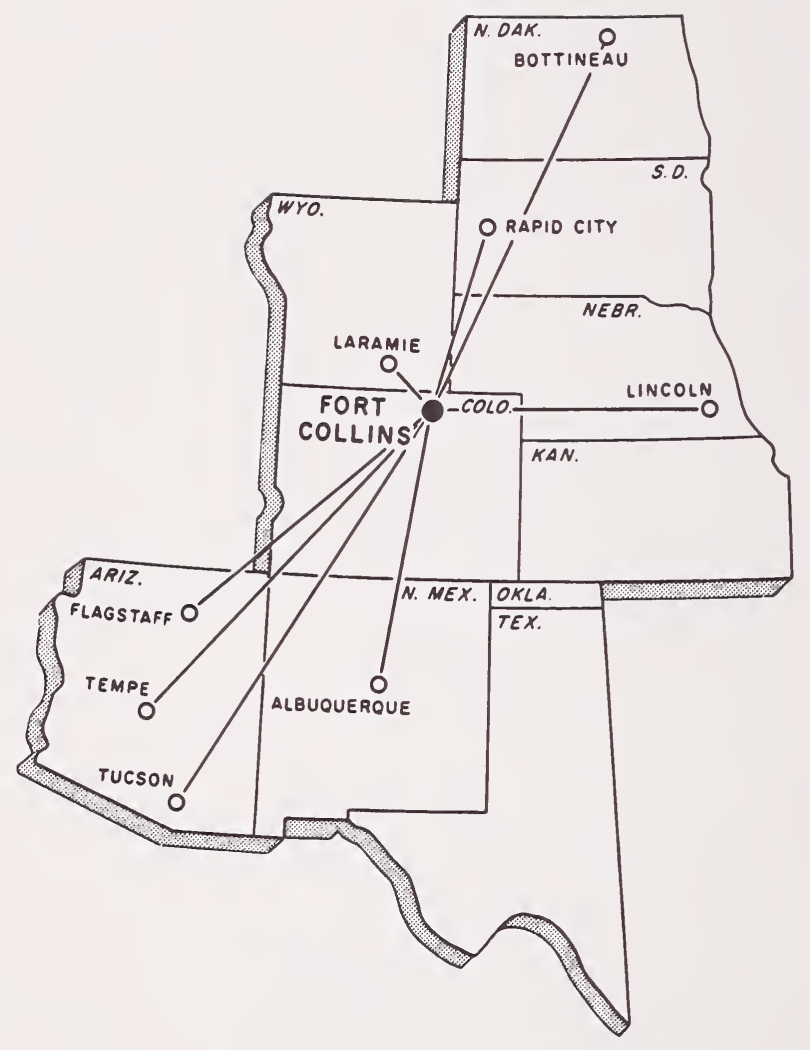

